\title{
Serum lipid growth curves for children and adolescents in predicting adult dyslipidemia (Data from the Slovak Lipid Community Study)
}

\author{
${\text { Roman } \text { Alberty }^{1 *} \text {, Dáša Albertyová }}^{2}$ \\ ${ }^{1}$ Department of Biology, Matthias Belivs University, Banská Bystrica, Slovakia \\ ${ }^{2}$ Department of Clinical Biochemistry, F. D. Roosevelt Hospital, Banská Bystrica, Slovakia \\ Email: ${ }^{\text {roman.alberty@umb.sk }}$
}

Received 8 August 2013; revised 15 September 2013; accepted 29 September 2013

Copyright @ 2013 Roman Alberty, Dáša Albertyová. This is an open access article distributed under the Creative Commons Attribution License, which permits unrestricted use, distribution, and reproduction in any medium, provided the original work is properly cited.

\begin{abstract}
Objectives: To create age- and sex-specific growth curves for serum lipids in Slovak children and adolescents, and to compare age- and sex-specific cut-off points with the currently recommended procedure using a single set of risk values for the whole child and adolescent population. Methods: Data were extracted from a cross-sectional Slovak Lipid Community Study conducted in 2005-2007; 873 healthy children and adolescents aged 7 - 18 years were selected for this study. Smoothed percentile curves were generated by LMS Pro software. Results: All lipid parameters (except for total cholesterol and LDL-cholesterol in girls) were higher in puberty than in adolescence, with the lowest serum lipids between the ages of 15 and 16 years. Mean triglyceride levels were higher in girls than in boys in all age groups. At the age of 18 years, about $19 \%$ boys and $25 \%$ girls had borderline and $6 \%$ boys and $15 \%$ girls had elevated total cholesterol. Elevated triglyceride levels were seen in $13 \%$ of boys and $11 \%$ of girls while abnormally low levels of HDL-cholesterol were found in $\mathbf{1 7 \%}$ of boys and $10 \%$ of girls. Conclusions: The results of this study suggest that 1) age and gender play a strong role in lipid measurements in children and adolescents, 2) Slovak children and adolescents have a relative high proportion of abnormal lipid levels, and 3 ) age- and sex-specific cut-off points for serum lipids could be used to identify children and adolescents with an elevated risk of dyslipidemia in adulthood.
\end{abstract}

Keywords: Children and Adolescent Health; Growth

"Corresponding author.
Standards; Dyslipidemia; Cardiovascular Disease

\section{INTRODUCTION}

Dyslipidemia is considered to be one of the main risk factors for cardiovascular disease (CVD) [1]. It is well known that abnormal lipid levels appear in childhood and may result in early atherosclerotic changes [2]. From this point of view, the effort to diagnose and treat dyslipidemia in children and youths is rationale.

The National Cholesterol Education Program (NCEP) pediatric report issued a single set of cut-off points for children and adolescents aged 2 - 19 years that can be used to identify those with abnormal lipid levels of total cholesterol (TC), low-density lipoprotein cholesterol (LDL-C), high-density lipoprotein cholesterol (HDL-C) and triglycerides (TG) [3]. The Slovak Pediatric Society and Slovak Association of Atherosclerosis have recently made a similar step and published a single conformable set of cut-off points for Slovak children and adolescents [4].

However, the fundamental problem here is that these currently recommended cut-off points do not take into account the fact that in the period of growth and maturation, there is a considerable variation in lipid concentrations, which is influenced by sex hormones, growth development and behavioral factors [5-7].

In this study, we attempted to set up growth curves for routine lipid parameters (TC, LDL-C, HDL-C and TG) for boys and girls aged 7 - 18 and highlighted the advantages of their use in predicting an elevated risk of dyslipidemia in adulthood.

\section{MATERIALS AND METHODS}

Details of the study population, design, survey method, 
and laboratory procedures have been described elsewhere [8]. The key points are summarized below.

\subsection{Study Population}

The present study reevaluated the data from 873 healthy children and adolescents aged 7 - 18 that had been collected in a cross-sectional population based Slovak Lipid Community Study (SLCS, 2005-2007) [8,9]. Their baseline clinical and lifestyle characteristics at the time of blood sampling are presented in Table 1.

\subsection{Laboratory Procedures}

Blood samples were obtained after overnight fasting. Serum levels of TC, HDL-C and TG were determined at the Central Clinical Laboratory at the F. D. Roosevelt Hospital (Banská Bystrica, Slovakia) by enzymatic methods on an Olympus AU 2700 analyzer (Olympus Diagnostics Systems, Melville, NY, USA) as described previously [8]. LDL-C was calculated from the Friedewald formula: TC - HDL-C - TG/2.2 = LDL-C [10]. Intra- and inter-assay coefficients of variation for the lipid measurements performed during the course of this study were $<3 \%$.

\subsection{Cut-Off Points for Abnormal Lipid Profile}

The cut-off points for serum lipid levels were based on the Slovak pediatric panel recommendations [4]. TC levels were elevated if they were $\geq 4.85 \mathrm{mmol} / \mathrm{l}$ and borderline if between 4.10 - $4.85 \mathrm{mmol} / \mathrm{l}$. LDL-C levels were considered elevated if they were $\geq 3.25 \mathrm{mmol} / \mathrm{l}$ and borderline if between 2.60 - $3.25 \mathrm{mmol} / \mathrm{l}$. HDL-C levels were considered low if $\leq 0.85 \mathrm{mmol} / \mathrm{l}$ and borderline if it

Table 1. Baseline clinical and lifestyle characteristics for Slovak children and adolescents 7 - 18 of age.

\begin{tabular}{|c|c|c|c|}
\hline Parameter & $\begin{array}{c}\text { boys } \\
(n=480)\end{array}$ & $\begin{array}{c}\text { girls } \\
(\mathrm{n}=393)\end{array}$ & $P$-value \\
\hline Age, years & $12.6(3.9)^{*}$ & $12.6(3.7)$ & NS \\
\hline Body mass index, kg/m² & $19.1(4.0)$ & $18.3(3.8)$ & 0.017 \\
\hline Overweight and obesity, \% & $54(11.4)$ & $32(8.1)$ & NS \\
\hline $\begin{array}{l}\text { Mean arterial pressure, } \\
\text { mmHg }\end{array}$ & $82.5(9.2)$ & $78.4(9.2)$ & $<0.001$ \\
\hline $\begin{array}{l}\text { Total cholesterol, } \\
\mathrm{mmol} / \mathrm{l}\end{array}$ & $3.80(0.77)$ & $3.89(0.70)$ & NS \\
\hline $\begin{array}{l}\text { LDL cholesterol, } \\
\mathrm{mmol} / \mathrm{l}\end{array}$ & $2.23(0.58)$ & $2.27(0.57)$ & NS \\
\hline $\begin{array}{l}\text { HDL cholesterol, } \\
\mathrm{mmol} / \mathrm{l}\end{array}$ & $1.15(0.28)$ & $1.16(0.28)$ & NS \\
\hline Triglycerides, mmol/l & $0.92(0.48)$ & $1.01(0.47)$ & 0.031 \\
\hline Current smoking, \% & 59 (12.3) & $35(9.0)$ & NS \\
\hline Low physical activity, \% & $165(34.3)$ & $165(42.3)$ & $<0.001$ \\
\hline
\end{tabular}

*Data are expresssed as mean (SD) or $n(\%)$. is between $1.10-0.85 \mathrm{mmol} / \mathrm{l}$ (boys) or $1.25-0.85$ $\mathrm{mmol} / \mathrm{l}$ (girls). TG levels were considered elevated $\geq 1.5$ $\mathrm{mmol} / \mathrm{l}$ and borderline between 1.15 - $1.50 \mathrm{mmol} / \mathrm{l}$.

\subsection{Statistical Methods}

The results are presented as mean (SD) and selected percentile values. Differences in continuous variables were tested using Student t-test for unpaired data, and differences in categorical variables by $\chi^{2}$-test. A $P$-value < 0.05 was considered significant. The LMS (Lambda, Mu, and Sigma) method was used for smoothed age- and sex-specific percentile curves (LMS Pro software, UCL Institute of Child Health, London, UK) [11].

\section{RESULTS}

The mean (SD) and empirical $50^{\text {th }}, 75^{\text {th }}, 90^{\text {th }}$ and $95^{\text {th }}$ percentiles of TC, LDL-C and TG $\left(5^{\text {th }}, 10^{\text {th }}, 25^{\text {th }}\right.$ and $50^{\text {th }}$ of HDL-C) by age and gender are summarized in Tables 2-5. Figures 1(a), 2(a), 3(a), 4(a) present the smoothed percentile curves graphically for boys and Figures 1(b), 2(b), 3(b), 4(b) present the smoothed percentile curves graphically for girls. The charts also show the elevated (as abnormal) and borderline elevated cut-off points from Slovak recommendations, as related to the age of 18 years in our analysis.

The TC growth curves for boys and girls had different trajectories. Whereas the male TC curves showed a clear increase in boys aged 11 - 14, the female curves declined during early children and puberty until the 15 - 16 of age

Table 2. Age- and sex-specific percentile values for serum total cholesterol (mmol/l) for Slovak children and adolescents 7 - 18 of age.

\begin{tabular}{|c|c|c|c|c|}
\hline Boys & $\begin{array}{l}-10 \\
\text { years }\end{array}$ & $\begin{array}{l}11-14 \\
\text { years }\end{array}$ & $\begin{array}{c}15-16 \\
\text { years }\end{array}$ & $\begin{array}{c}17-18 \\
\text { years }\end{array}$ \\
\hline$n$ & 139 & 130 & 107 & 104 \\
\hline Mean (SD) & $3.75(0.76)$ & $4.12(0.78)$ & $3.63(0.69)$ & $3.66(0.71)$ \\
\hline $50^{\text {th }}$ percentile & 3.71 & 4.08 & 3.59 & 3.60 \\
\hline $75^{\text {th }}$ percentile & 4.34 & 4.50 & 4.11 & 4.14 \\
\hline $90^{\text {th }}$ percentile & 4.76 & 5.26 & 4.52 & 4.63 \\
\hline $95^{\text {th }}$ percentile & 4.92 & 5.46 & 4.85 & 4.88 \\
\hline \multicolumn{5}{|l|}{ Girls } \\
\hline$n$ & 122 & 112 & 93 & 66 \\
\hline Mean (SD) & $3.98(0.76)$ & $3.95(0.59)$ & 3.59 (0.67) & $4.08(0.70)$ \\
\hline $50^{\text {th }}$ percentile & 3.92 & 3.90 & 3.64 & 4.03 \\
\hline $75^{\text {th }}$ percentile & 4.50 & 4.38 & 4.17 & 4.37 \\
\hline $90^{\text {th }}$ percentile & 4.97 & 4.90 & 4.56 & 4.83 \\
\hline $95^{\text {th }}$ percentile & 5.49 & 5.00 & 4.83 & 5.68 \\
\hline
\end{tabular}


Table 3. Age- and sex-specific percentile values for serum LDL cholesterol (mmol/l) for Slovak children and adolescents 7 - 18 of age.

\begin{tabular}{|c|c|c|c|c|}
\hline Boys & $\begin{array}{l}7-10 \\
\text { years }\end{array}$ & $\begin{array}{l}11-14 \\
\text { years }\end{array}$ & $\begin{array}{c}15-16 \\
\text { years }\end{array}$ & $\begin{array}{c}17-18 \\
\text { years }\end{array}$ \\
\hline$n$ & 139 & 130 & 107 & 104 \\
\hline Mean (SD) & $2.22(0.55)$ & $2.40(0.66)$ & $2.10(0.52)$ & $2.14(0.52)$ \\
\hline $50^{\text {th }}$ percentile & 2.25 & 2.34 & 2.11 & 2.13 \\
\hline $75^{\text {th }}$ percentile & 2.55 & 2.67 & 2.49 & 2.57 \\
\hline $90^{\text {th }}$ percentile & 2.96 & 3.25 & 2.80 & 2.90 \\
\hline $95^{\text {th }}$ percentile & 3.20 & 3.68 & 3.02 & 3.00 \\
\hline \multicolumn{5}{|l|}{ Girls } \\
\hline$n$ & 122 & 112 & 93 & 66 \\
\hline Mean (SD) & $2.45(0.63)$ & $2.25(0.51)$ & $2.01(0.54)$ & $2.40(0.51)$ \\
\hline $50^{\text {th }}$ percentile & 2.36 & 2.27 & 1.99 & 2.32 \\
\hline $75^{\text {th }}$ percentile & 2.71 & 2.56 & 2.37 & 2.68 \\
\hline $90^{\text {th }}$ percentile & 3.27 & 2.95 & 2.72 & 3.16 \\
\hline $95^{\text {th }}$ percentile & 3.89 & 3.30 & 3.18 & 3.39 \\
\hline
\end{tabular}

Table 4. Age- and sex-specific percentile values for serum HDL cholesterol (mmol/l) for Slovak children and adolescents 7 - 18 of age.

\begin{tabular}{lcccc}
\hline Boys & $\begin{array}{c}\mathbf{7 - 1 0} \\
\text { years }\end{array}$ & $\begin{array}{c}\mathbf{1 1}-\mathbf{1 4} \\
\text { years }\end{array}$ & $\begin{array}{c}\mathbf{1 5}-\mathbf{1 6} \\
\text { years }\end{array}$ & $\begin{array}{c}\mathbf{1 7} \mathbf{- 1 8} \\
\text { years }\end{array}$ \\
\hline$n$ & 139 & 130 & 107 & 104 \\
Mean (SD) & $1.13(0.29)$ & $1.27(0.28)$ & $1.09(0.26)$ & $1.07(0.25)$ \\
$5^{\text {th }}$ percentile & 0.66 & 0.85 & 0.73 & 0.68 \\
$10^{\text {th }}$ percentile & 0.76 & 0.92 & 0.81 & 0.79 \\
$25^{\text {th }}$ percentile & 0.91 & 1.07 & 0.90 & 0.87 \\
$50^{\text {th }}$ percentile & 1.16 & 1.25 & 1.06 & 1.06 \\
Girls & & & & \\
$n$ & 122 & 112 & 93 & 66 \\
Mean $(S D)^{\text {th }}$ percentile & $1.10(0.31)$ & $1.22(0.26)$ & $1.16(0.23)$ & $1.22(0.30)$ \\
$10^{\text {th }}$ percentile & 0.66 & 0.87 & 0.75 & 0.79 \\
$25^{\text {th }}$ percentile & 0.89 & 1.04 & 1.00 & 0.97 \\
$50^{\text {th }}$ percentile & 1.07 & 1.19 & 1.14 & 1.21 \\
\hline
\end{tabular}

before a strong increasing to approach adult TC concentrations. On the basis of diagnostic criteria for dyslipidemia in Slovakia, about $19 \%$ of boys and $25 \%$ of girls had borderline elevated and $6 \%$ of boys and $15 \%$ of girls had elevated TC at the age of 18.

Serum LDL-C for both boys and girls followed the
Table 5. Age- and sex-specific percentile values for serum triglycerides (mmol/l) for Slovak children and adolescents 7 18 of age.

\begin{tabular}{lcccc}
\hline Boys & $\begin{array}{c}\mathbf{7 ~ - ~ 1 0} \\
\text { years }\end{array}$ & $\begin{array}{c}\mathbf{1 1 ~ - ~ 1 4} \\
\text { years }\end{array}$ & $\begin{array}{c}\mathbf{1 5 ~ - ~ 1 6} \\
\text { years }\end{array}$ & $\begin{array}{c}\mathbf{1 7 - 1 8} \\
\text { years }\end{array}$ \\
\hline$n$ & 139 & 130 & 107 & 104 \\
Mean (SD) & $0.86(0.43)$ & $0.96(0.48)$ & $0.92(0.45)$ & $0.99(0.58)$ \\
$50^{\text {th }}$ percentile & 0.76 & 0.86 & 0.83 & 0.84 \\
$75^{\text {th }}$ percentile & 1.01 & 1.16 & 1.12 & 1.22 \\
$90^{\text {th }}$ percentile & 1.37 & 1.61 & 1.60 & 1.76 \\
$95^{\text {th }}$ percentile & 1.60 & 1.83 & 1.74 & 2.13 \\
Girls & & & & \\
$n$ & 122 & 112 & 93 & 66 \\
Mean (SD) & $0.96(0.43)$ & $1.07(0.54)$ & $0.97(0.42)$ & $1.04(0.42)$ \\
$50^{\text {th }}$ percentile & 0.89 & 0.97 & 0.88 & 0.95 \\
$75^{\text {th }}$ percentile & 1.05 & 1.24 & 1.11 & 1.20 \\
$90^{\text {th }}$ percentile & 1.48 & 1.58 & 1.50 & 1.74 \\
$95^{\text {th }}$ percentile & 1.80 & 2.08 & 1.74 & 2.01 \\
\hline
\end{tabular}

similar age-related trend as that for TC, but in girls its decline was much more obvious. Fifteen percent of boys and $21 \%$ of girls had borderline elevated while $3 \%$ of boys and $8 \%$ of girls showed elevated LDL-C at the age of 18.

HDL-C serum levels are higher in boys than in girls during puberty. After the end of puberty, HDL-C levels in boys decreased considerably whereas in girls the values gradually increase mildly from puberty to adulthood. The borderline low serum levels of HDL-C were found in $45 \%$ of boys and $57 \%$ of girls and abnormal low levels in $17 \%$ of boys and in $10 \%$ of girls at the age of 18 .

Serum levels of TG temporarily increase both in boys and girls during early childhood and puberty and subsequently fall slightly. A pronounced increase appears at the age of $17-18$, especially in boys. Overall, however, girls had significantly higher mean TG levels than boys. Seventeen percent of boys and 13\% of girls had borderline elevated and $13 \%$ of boys and $11 \%$ of girls had elevated TG serum levels at the age of 18 .

\section{DISCUSSION}

In this study we establish for the first time the smoothed growth curves for TC, LDL-C, HDL-C and TG in the healthy Slovak population of 873 children and adolescents aged 7 - 18 years. The growth curves demonstrate that serum lipids change dynamically during puberty and adolescence, often in a different manner between boys and girls. In addition, the reference values derived from 


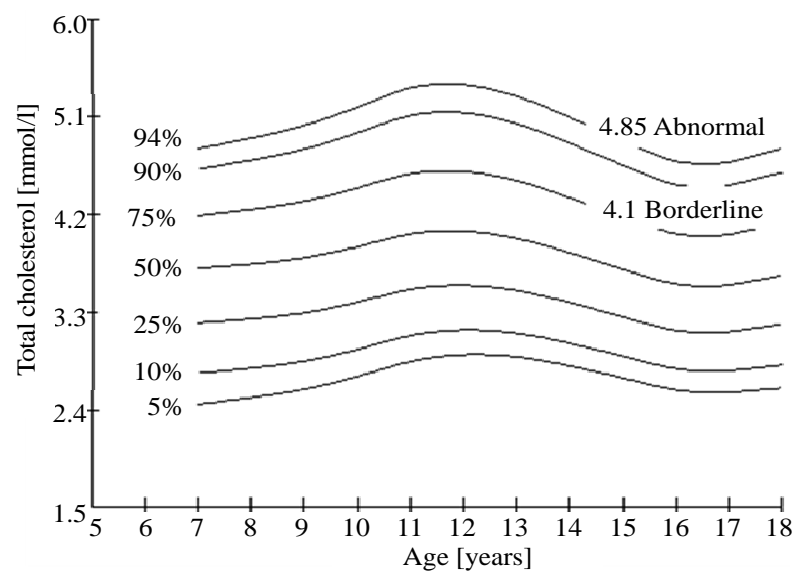

(a)

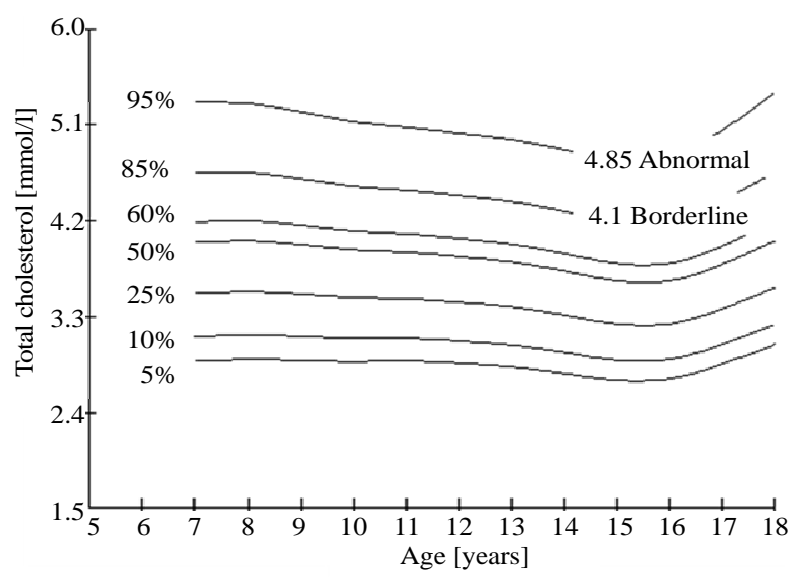

(b)

Figure 1. (a) Smoothed percentile curves for serum total cholesterol for Slovak boys $7-18$ years of age: $94^{\text {th }}$ and $75^{\text {th }}$ percentile curve passes through 4.85 and $4.10 \mathrm{mmol} / \mathrm{l}$ respectively at 18 years. (b) Smoothed percentile curves for serum total cholesterol for Slovak girls 7 - 18 years of age: $85^{\text {th }}$ and $60^{\text {th }}$ percentile curve passes through 4.85 and $4.10 \mathrm{mmol} / \mathrm{l}$ respectively at 18 years.

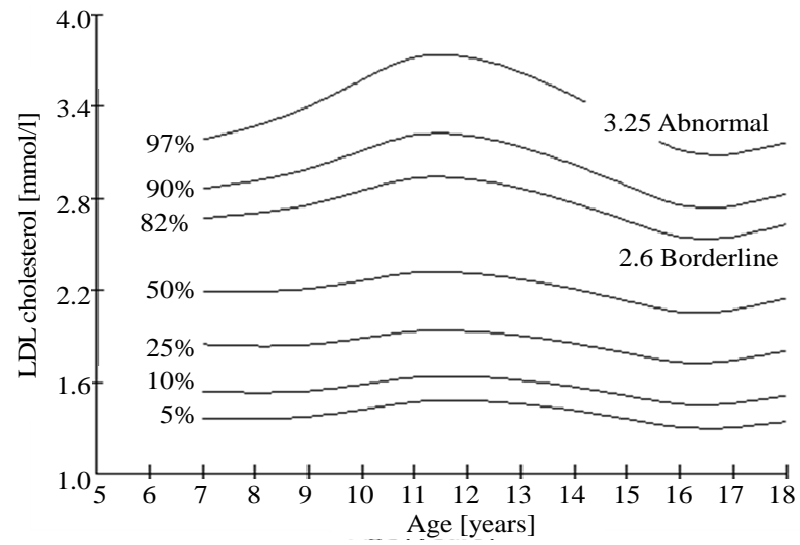

(a)

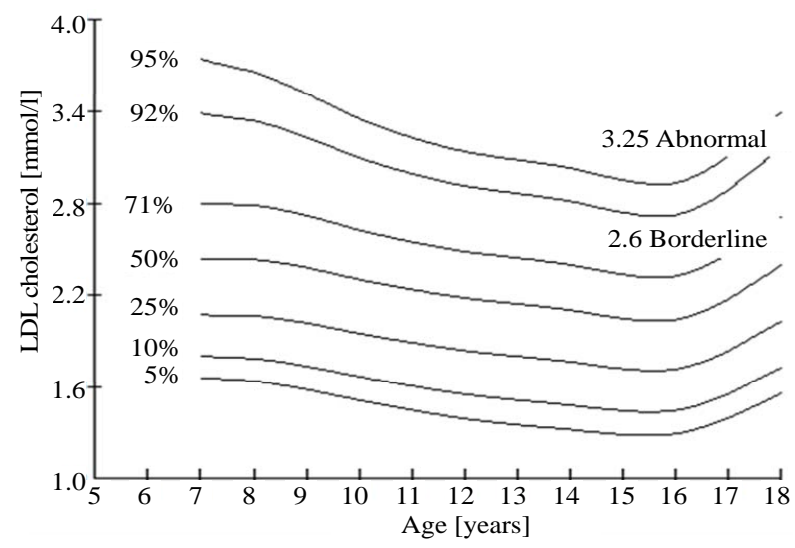

(b)

Figure 2. (a) Smoothed percentile curves for serum LDL cholesterol for Slovak boys 7 - 18 years of age: $97^{\text {th }}$ and $82^{\text {nd }}$ percentile curve passes through 3.25 and $2.60 \mathrm{mmol} / \mathrm{l}$ respectively at 18 years. (b) Smoothed percentile curves for serum LDL cholesterol for Slovak girls 7 - 18 years of age: $92^{\text {nd }}$ and $71^{\text {st }}$ percentile curve passes through 3.25 and $2.60 \mathrm{mmol} / \mathrm{l}$ respectively at 18 years.

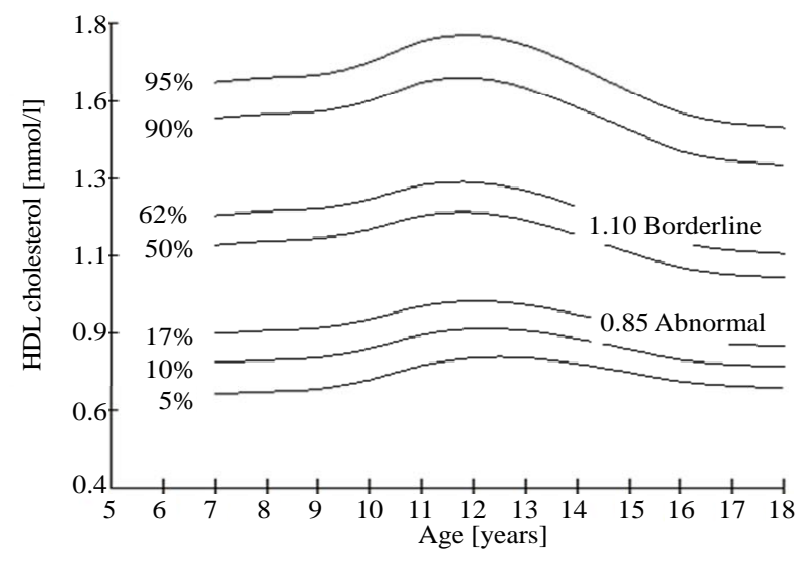

(a)

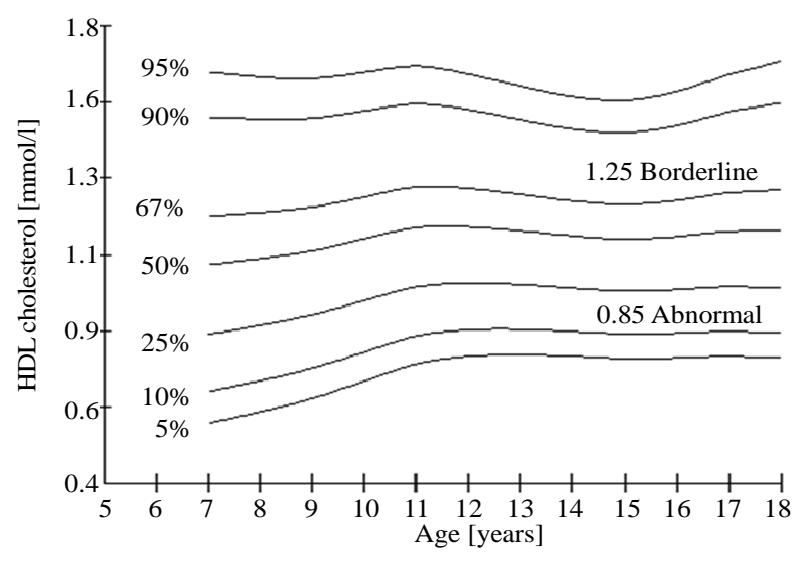

(b)

Figure 3. (a) Smoothed percentile curves for serum HDL cholesterol for Slovak boys 7 - 18 years of age: $17^{\text {th }}$ and $62^{\text {nd }}$ percentile curve passes through 0.85 and $1.10 \mathrm{mmol} / \mathrm{l}$ respectively at 18 years. (b) Smoothed percentile curves for serum HDL cholesterol for Slovak girls 7 - 18 years of age: $10^{\text {th }}$ and $67^{\text {th }}$ percentile curve passes through 0.85 and $1.25 \mathrm{mmol} / \mathrm{l}$ respectively at 18 years. 


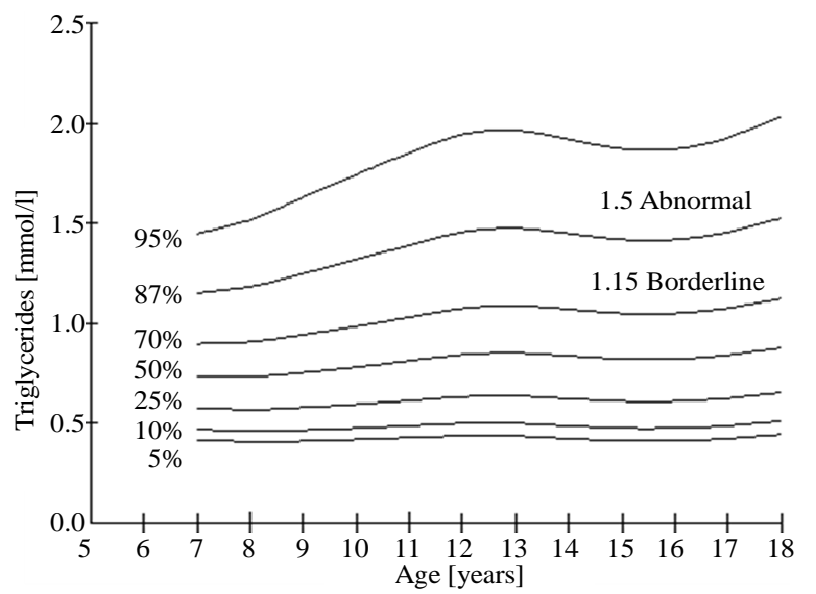

(a)

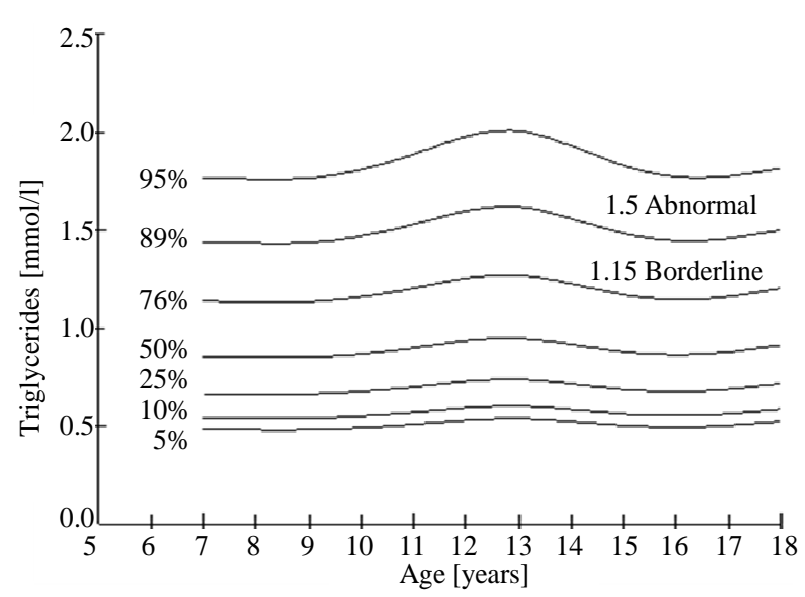

(b)

Figure 4. (a) Smoothed percentile curves for serum triglycerides for Slovak boys 7 - 18 years of age: $87^{\text {th }}$ and $70^{\text {th }}$ percentile curve passes through 1.5 and $1.15 \mathrm{mmol} / \mathrm{l}$ respectively at 18 years. (b) Smoothed percentile curves for serum triglycerides for Slovak girls 7 - 18 years of age: $89^{\text {th }}$ and $76^{\text {th }}$ percentile curve passes through 1.5 and $1.15 \mathrm{mmol} / \mathrm{l}$ respectively at 18 years.

these curves enable to identify the same proportion of children and adolescents with an elevated risk of dyslipidemia at each age.

During childhood, the serum TC and TG levels tend to be lower than during adulthood [12]. However, TC and TG levels in children and adolescents increase physiologically and such a disproportional increase is related to the higher risk of atherosclerosis and CVD in adulthood. The studies which investigate approximately the same age group as our study usually describe a characteristic bimodal distribution of both TC and TG levels. The first considerable increase in TC and TG levels appears in puberty, and the second increase of TC and TG can be seen at the end of adolescence.

More recently, in the National Health and Nutrition Examination Survey (NHANES, 1988-2010) report the data describing lipid profile in children aged 6 - 19 have shown that children between 9 to 11 years old had the highest mean TC level among all the age groups [13]. Similar age-related TC distribution but with much lower mean TC levels than in US children have been reported in non-obese Indian schoolchildren of Delhi age of 6 - 17 [14].

TG is the serum lipid group with the largest short- and long-term variability [15]. From the age of 1 its levels already begin to increase, which is said to be related to the increasing proportion of carbohydrates (particularly sucrose and fructose) in children's diet [16]. Data compiled from several renowned American population studies have uncovered bimodal fluctuation of serum TG levels in girls with the initial peak at the age of 11 and the second peak at the age of 20, while in boys serum TG increased with age in a linear manner [17].

The increase of both TC and TG levels during puberty may be a result of the increased insulin resistance that appears in children during early puberty [18]. In our study, both mean TC and TG levels in boys and TG levels in girls were highest at 11 - 14 years and thereafter their levels decreased by 5\% - 15\% among adolescents aged 15 - 16 years. The fact that mean TC levels measured by us are considerably lower in comparison with the values measured in the US children may be related to race/ethnicity differences, behavioral or environmental factors, or it may be caused by the differences in the methods employed. Overall, however, a favorable trend in serum lipid concentrations was observed among US youths and adults over recent decades [13,19].

LDL-C is the major atherogenic fraction of lipoproteins with which the primary prevention and hypolipidemic therapy is concerned [20]. The dynamics of LDL$\mathrm{C}$ changes during puberty and adolescence more or less mirror the changes in TC levels, since LDL transports approximately $50 \%$ - $60 \%$ of the cholesterol in serum during childhood. In the present study, the changes in LDL-C levels become much more closely related to TC levels in younger, male-gendered subjects. This finding also corresponds with the larger discrepancy between the prevalence of elevated and borderline elevated values of LDL-C and TC in girls. However, we cannot provide a reliable explanation for the initially high and then steadily declined serum levels of TC and LDL-C in girls during the juvenile and pubertal period.

Low HDL-C is a risk factor for CVD independently of levels of LDL-C [21]. It is well known that men tend to have noticeably lower HDL-C levels than women [22]. In children it does not necessarily have to be that clear. For example, in a sample of 420 children from Istanbul aged 0 - 15 there was no considerable difference proven between HDL-C levels in boys and in girls [23]. Interestingly, these levels were relatively stable in both gen- 
ders after the age of 1 . In our study, the mean HDL-C levels in children aged 7 - 18 was also the same for both sexes. However, our data imply that HDL-C levels were higher in boys during puberty, while in girls they were higher in adolescence; optimal serum HDL-C levels were found in $36 \%$ subjects only. Similarly to other studies, we showed that men are at greater risk of having dangerous low HDL-C levels than women [22].

The presented age- and sex-related findings about the dynamics of changes in serum lipid levels are of great importance in the optimal timing and the choice of a single set of cut-off points for the screening of dyslipidemia in a whole population of children and adolescents.

The Slovak pediatric panel has published a single set of cut-off points which should be used to identify children and adolescents with abnormal and borderline levels of TC, LDL-C, HDL-C and TG; there are lower than cut-off points based on the NCEP pediatric guidelines [4]. Furthermore, the recommendations propose a universal TC screening for children 11 and 17 of age. The implementation of this national strategy for TC is illustrated in Figures 5(a) and (b).

It is clear that the currently stipulated single cut-off point(s) for (borderline) elevated TC does not reflect the physiological changes in serum TC levels which appear in boys and girls at a given age. For example, the prevalence of elevated TC in puberty children was $14.0 \%$ for Slovak fixed-point recommendations or $5.3 \%$ for ageand sex-specific threshold values derived from SLCS growth curve data. From another source, Ministry of Health of the Slovak Republic in 2009-2011 performed a universal screening of elevated serum TC in sample of 8 689 children of age 11 and 17 years. Based on the current

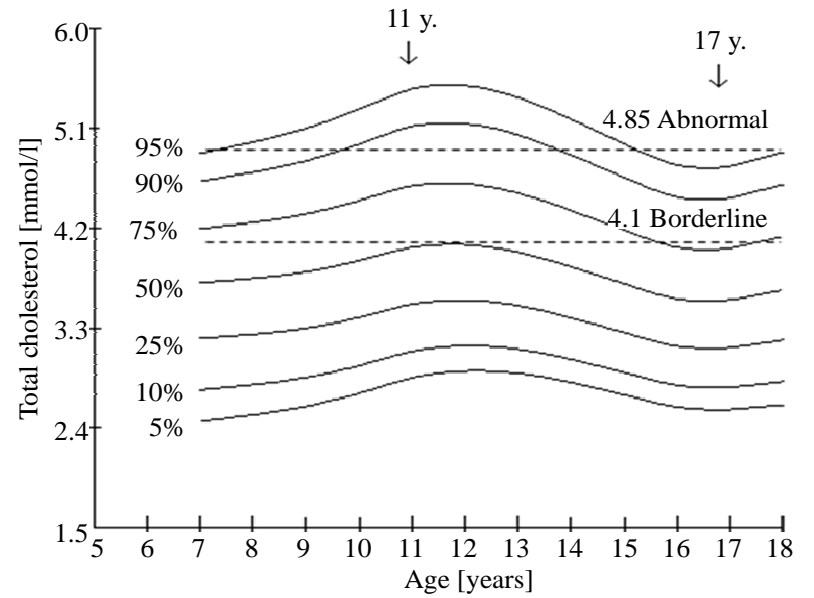

(a) recommendations, the relative risk (RR) of an elevated TC level is nearly 2 times higher (RR 1.685, 95\% CI 1.514 - 1.876) in children during puberty than in adolescents (unpublished observations). In our opinion, such risk prevalence disproportion is improbable because both age groups always come from the same population sample, and none of the adolescent subjects took hypolipidemic medication.

Age-based percentile distributions are commonly used to define risk presence for both hypertension and overweight $[24,25]$. In this study, we provide the age- and sex-specific cut-off points for the distribution of TC for Slovak children and adolescents (Table 6). They facilitate the identification of hypercholesterolemia more effectively than the currently fixed-points recommendations. Several authors share this opinion with us. To sum up: 1) the age- and sex-specific threshold values reflect the natural fluctuation of serum lipids that occur with growth and maturation, 2) the reference values from the growth curves enable to identify the same proportion of at-risk children at each age, and 3) children usually keep their percentile distribution ranking the same which enables to foresee the changes in their lipid levels until young adult age $[26,27]$. As pointed out by Friedman et al. [28] the sensitivity and specificity of serum lipids for predicting adult lipid and CVD status vary with the age (mainly in the pubertal period) at which the pediatric lipid determination was made.

However, the growth curves presented here have two potential limitations which we should recognize. There was a cross-sectional analysis of existing data and we examined a relatively small number of children and adolescents. The strength of this study resides in the meas-

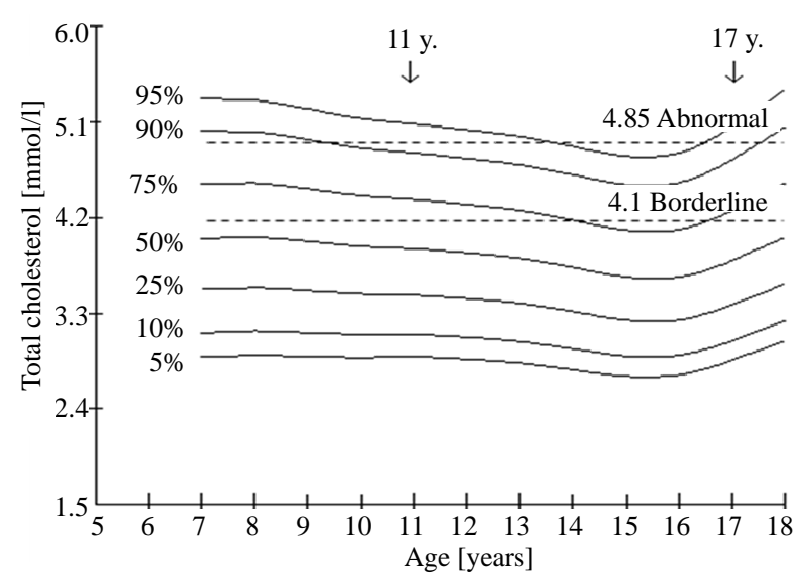

(b)

Figure 5. (a) Smoothed percentile curves for serum total cholesterol for Slovak boys 7 - 18 years of age. The dashed lines represent a universal cut-off points and arrows indicate the age period when serum lipid measurement should be made (based on the Slovak Pediatric Society recommendations). (b) Smoothed percentile curves for serum total cholesterol for Slovak girls 7 - 18 years of age. The dashed lines represent a universal cut-off points and arrows indicate the age period when serum lipid measurement should be made (based on the Slovak Pediatric Society recommendations). 
Table 6. Age- and sex-specific cut-off points derived from growth curves for serum total cholesterol (mmol/l) and corresponding percentile values for Slovak children and adolescents 7 - 18 of age.

\begin{tabular}{ccccc}
\hline \multirow{2}{*}{ Age, $\mathbf{y}$. } & \multicolumn{2}{c}{ Goys } & \multicolumn{2}{c}{ Girls } \\
\cline { 2 - 5 } & borderline $\mathbf{7 5}^{\text {th }}$ percentile & abnormal $\mathbf{9 4}^{\text {th }}$ percentile & borderline $\mathbf{6 0}^{\text {th }}$ percentile & abnormal 85 $^{\text {th }}$ percentile \\
\hline 7 & 4.19 & 4.78 & 4.20 & 4.81 \\
8 & 4.26 & 4.92 & 4.19 & 4.79 \\
9 & 4.33 & 5.04 & 4.15 & 4.73 \\
10 & 4.45 & 5.21 & 4.12 & 4.65 \\
11 & 4.58 & 5.35 & 4.08 & 4.62 \\
12 & 4.62 & 5.39 & 4.05 & 4.57 \\
13 & 4.50 & 5.24 & 4.00 & 4.42 \\
14 & 4.37 & 5.11 & 3.88 & 4.35 \\
15 & 4.17 & 4.86 & 3.81 & 4.33 \\
16 & 3.98 & 4.70 & 3.82 & 4.52 \\
17 & 4.01 & 4.74 & 3.96 & 4.85 \\
\hline
\end{tabular}

urement of lipid parameters in a few analytical runs at the same Central Clinical Laboratory (F. D. Roosevelt Hospital).

\section{CONCLUDING REMARKS}

This study presents a series of growth distribution curves describing the dynamic changes in serum lipids in children during puberty and adolescence. Our findings indicate that using the age- and sex-specific cut-off points facilitates the detection of dyslipidemia in a more effective way than the currently recommended strategy based on the same threshold values for the whole child and adolescent population. However, further prospective studies will have to be done to validate our findings and to obtain representative reference values for our population.

\section{ACKNOWLEDGEMENTS}

The study was financially supported by the Ministry of Education, Science and Research of the Slovak Republic (VEGA 1/2345-05).

\section{REFERENCES}

[1] Khot, U.N., Khot M.B., Bajzer, T.C., Sapp, S.K., Ohman, E.M., Brener, S.J., Ellis, S.G., Lincoff, A.M. and Topol, E.J. (2003) Prevalence of conventional risk factors in patients with coronary heart disease. JAMA, 290, 898-904. http://dx.doi.org/10.1001/jama.290.7.898

[2] McGill, H.C. jr., McMahan, C.A., Malcom, G.T., Oalmann, M.C. and Strong, J.P. (1997) Effects of serum lipoproteins and smoking on atherosclerosis in young men and women. The PDAY Research Group. Pathobiological Determinants of Atherosclerosis in Youth. Arteriosclerosis, Thrombosis, and Vascular Biology, 17, 95-106. http://dx.doi.org/10.1161/01.ATV.17.1.95

[3] National Cholesterol Education Program (NCEP). Highlights of the report of the expert panel on blood cholesterol levels in children and adolescents (1992) Pediatrics, 59, 495-501.

[4] Recommendations for diagnosis and treatment of dyslipidemia in children and adolescents (2011) Cardiology Letters, 20, 254-261.

[5] Morrison, J.A., Barton, B.A., Biro, F.M. and Sprecher, D.L. (2003) Sex hormones and the changes in adolescent male lipids: longitudinal studies in a biracial cohort. Journal of Pediatrics, 142, 637-642. http://dx.doi.org/10.1067/mpd.2003.246

[6] Jelenkovic, A., Bogl, L.H., Rose, R.J., Kangas, A.J., Soininen, P., Ala-Korpela, M., Kaprio, J. and Silventoinen, K. (2013) Association of height and pubertal timing with lipoprotein subclass profile: Exploring the role of genetic and environmental effects. American Journal of Human Biology, 25, 465-472. http://dx.doi.org/10.1002/ajhb.22381

[7] Madhavan, M., Pandey, R.M., Misra, A., Vikram, N.K., Dhingra, V., Luthra, K. and Wasir, J.S. (2005) Centile values for serum lipids and blood pressure for Asian Indian adolescents. Lipids in Health and Disease, 4, 20. http://dx.doi.org/10.1002/ajhb.22381

[8] Alberty, R., Albertyová, D. and Ahlers, I. (2009) Distribution and correlations of non-high-density lipoprotein cholesterol in Roma and Caucasian children: The Slovak Lipid Community Study. Collegium Antropologicum, 4, 1015-1022.

[9] Alberty, R. and Albertyová, D. (2012) Lipoprotein(a) in 
children of Asian Indian descendants and their Caucasian neighbors: The Slovak Lipid Community Study. Indian Journal of Clinical Biochemistry, 27, 231-238. http://dx.doi.org/10.1007/s12291-012-0196-9

[10] Friedewald, W.T., Levy, R.I. and Fredrickson, D.S. (1972) Estimation of the concentration of low-density lipoprotein cholesterol in plasma, without use of the preparative ultra-centrifuge. Clinical Chemistry, 18, 499-502.

[11] Cole, T.J. (1990) The LMS method for constructing normalized growth standards. European Journal of Clinical Nutrition, 44, 45-60.

[12] Naito, H.K. (1996) Coronary artery disease and disorders of lipid metabolism. In: Kaplan, L.A. and Pesce, A.J., Eds., Clinical Chemistry: Theory, Analysis, and Correlation, Mosby, St. Louis, 642-681.

[13] Kit, B.K., Carroll, M.D., Lacher, D.A., Sorlie, P.D., DeJesus, J.M. and Ogden, C. (2012) Trends in serum lipids among US youths aged 6 to 19 years, 1988-2010. JAMA, 308, 591-600. http://dx.doi.org/10.1001/jama.2012.9136

[14] Marwaha, R.K., Khadgawat, R., Tandon, N., Kanwar, R., Narang, A., Sastry, A. and Bhadra, K. (2011) Reference intervals of serum lipid profile in healthy Indian school children and adolescents. Clinical Biochemistry, 44, 760766. http://dx.doi.org/10.1016/j.clinbiochem.2011.05.011

[15] Gidding, S.S., Stone, N.J., Bookstein, L.C., Laskarzewski, P.M. and Stein, E.A. (1998) Month-to-month variability of lipids, lipoproteins, and apolipoproteins and the impact of acute infection in adolescents. Journal of Pediatrics, 133, 242-246. http://dx.doi.org/10.1016/S0022-3476(98)70227-6

[16] Niinikoski, H. and Routtinen, S. (2012) Is carbohydrate intake in the first years of life related to future risk of NCDs? Nutrition, Metabolism \& Cardiovascular Diseases, 22, 770-774. http://dx.doi.org/10.1016/j.numecd.2012.05.002

[17] Cook, S., Auinger, P. and Huang, T.T. (2009) Growth curves for cardio-metabolic risk factors in children and adolescents. Journal of Pediatrics, 155, S6e15-26.

[18] Moran, A., Jacobs, D.R., Steinberger, J., Hong, C.-P., Prineas, R., Luepker, R. and Sinaiko, A.R. (1999) Insulin resistance during puberty: Results from clamp studies in 357 children. Diabetes, 48, 2039-2044. http://dx.doi.org/10.2337/diabetes.48.10.2039

[19] Carroll, M.D., Kit, B.K., Lacher, D.A., Shero, S.T. and Mussolino, M.E. (2012) Trends in lipids and lipoproteins in US adults, 1988-2010. JAMA, 308, 1545-1554. http://dx.doi.org/10.1001/jama.2012.13260

[20] Robinson, J.G., Bolland, L.L., McGovern, P.G., Folsom,
A.R. (2001) A comparison of NCEP and absolute risk stratification methods for lipid-lowering therapy in middle-aged adults: The ARIC study. The ARIC Investigators. Preventive Cardiology, 4, 148-157.

http://dx.doi.org/10.1111/j.1520-037X.2001.00562.x

[21] Boden, W.E. (2000) High-density lipoprotein cholesterol as an independent risk factor in cardiovascular disease: Assessing the data from Framingham to the Veterans Affairs High-Density Lipoprotein Intervention Trial. American Journal of Cardiology, 86, 19L-22L. http://dx.doi.org/10.1016/S0002-9149(00)01464-8

[22] Li, Z., Yang, R., Xu, G. and Xia, T. (2005) Serum lipid concentrations and prevalence of dyslipidemia in a large Professional population in Beijing. Clinical Chemistry, 51, 144-150. http://dx.doi.org/10.1373/clinchem.2004.038646

[23] Bahar, A., Sevgican, U., Karademir, F. and Gocmen, I. (2003) Serum cholesterol, triglyceride, VLDL-c, LDL-c, and HDL-c levels in healthy children. The Tohoku Journal of Experimental Medicine, 201, 75-80. http://dx.doi.org/10.1620/tjem.201.75

[24] National High Blood Pressure Education Program Working Group on High Blood Pressure in Children and Adolescents. The fourth report on the diagnosis, evaluation, and treatment of high blood pressure in children and adolescents. (2004) Pediatrics, 114, 555-576. http://dx.doi.org/10.1542/peds.114.2.S2.555

[25] Cole, T.J., Bellizzi, M.C., Flegal, K.M. and Dietz, W.H. (2000) Establishing a standard definition for child overweight and obesity worldwide: International survey. $B M J$, 320, 1240-1243.

http://dx.doi.org/10.1136/bmj.320.7244.1240

[26] Jolliffe, C.J. and Janssen, I. (2006) Distribution of lipoproteins by age and gender in adolescents. Circulation, 114, 1056-1062.

http://dx.doi.org/10.1161/CIRCULATIONAHA.106.6208 $\underline{64}$

[27] Webber, L.S., Srinivasan, S.R., Wattigney, W.A. and Berenson, G.S. (1991) Tracking of serum lipids and lipoproteins from childhood to adulthood: The Bogalusa Heart Study. American Journal of Epidemiology, 133, 884-899.

[28] Friedman, L.A., Morrison, J.A., Daniels, S.R., McCarthy, W.F. and Sprecher, D.L. (2006) Sensitivity and specifity of pediatric lipid determinations for adult lipid status: Findings from the Princeton Lipid Research Clinics Prevalence Program Follow-up Study. Pediatrics, 118, 165-172. http://dx.doi.org/10.1542/peds.2005-2968 